\title{
Seasonal Fluctuation of the Date Palm Fruit Stalk Borer, Oryctes elegans Prell (Coleoptera: Scarabaeidae), in Date Palm Plantations in Al-Qassim Region, Saudi Arabia
}

\author{
Mohammad Al-Deghairi \\ College of Agriculture and Veterinary Medicine, Qassim University, Buraydah, \\ P.O. Box 1482, Al-Qassim, Saudi Arabia

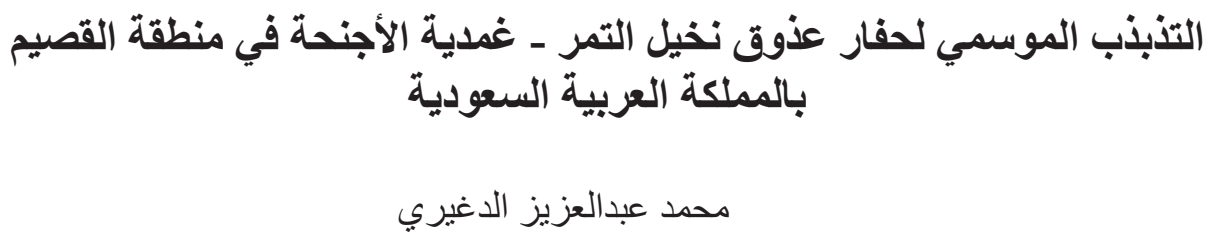

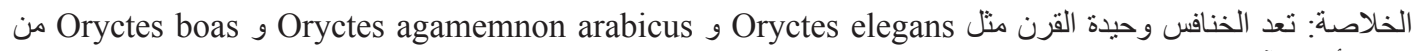
ضمن أخطر آفات نخيل التمر في المملكة العربية السعودية. ينتشر حفار عذوق النقان النخيل (Oryctes elegans) بشكل و واسع في جميع

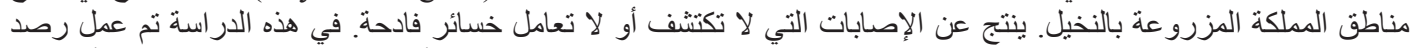

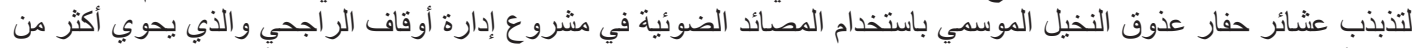

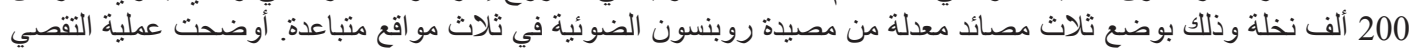

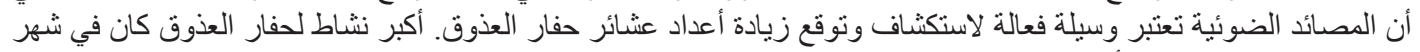

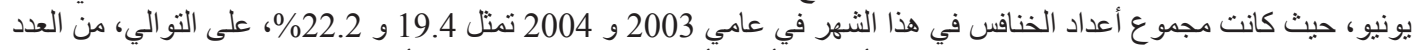

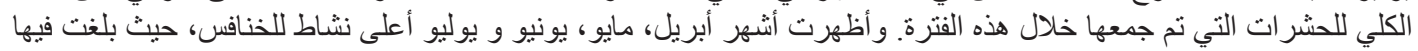

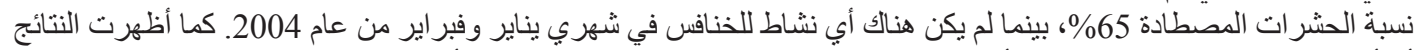

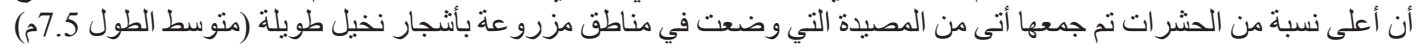

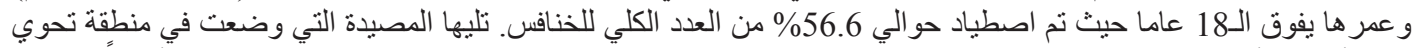

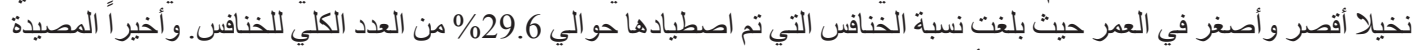

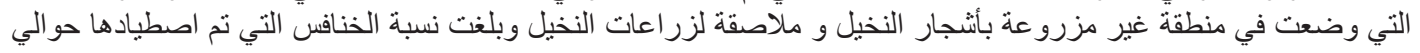
13.8 \% من العدد الكلي للخنافس.

\begin{abstract}
The date palm fruit stalk borer, Oryctes elegans, is widely distributed in Saudi Arabia. Undetected and untreated infestations by this pest result in severe losses. Light trap studies to investigate seasonal population fluctuations of $O$. elegans were conducted in Al-Rajhi Endowment date palm plantation in Al-Qassim, Saudi Arabia, by installing three modified Robinson mercury-vapor light traps in 3 different equidistant sites. The investigation revealed that light trapping is an effective tool for the monitoring and forecasting of O. elegans infestations. The highest activity of $O$. elegans was witnessed from April to July, during which period $65 \%$ of adults captures were made. Peak monthly activity was observed during June, when $19.4 \%$ and $22.2 \%$ of the catches were made during 2003 and 2004, respectively. No beetle activity was observed during January and February. The highest number of beetles (56.6\% of the population) was recovered in the site with relatively old and tall palms (more than 18 years old and averaging $7.5 \mathrm{~m}$ in height). The site with shorter and younger palms received $29.6 \%$ of the beetles, whereas the uncultivated site had the lowest number of beetles (13.8\% of total).
\end{abstract}

Keywords: Oryctes elegans, date palm, light trap monitoring. 


\section{Introduction}

More than four million date palm trees are grown in Al-Qassim region of Saudi Arabia, including some of the world's best varieties. Rhinoceros beetles (Coleoptera: Scarabaeidae), such as Oryctes elegans Prell, O. agamemnon arabicus Fairmaire, and $O$. boas Fabricius, are among the most notorious pests of date palms in Iraq, Pakistan, Iran and Saudi Arabia (Talhouk 1984, 1991; Martin, 1967, Gharib, 1970; Carpenter and Elmer, 1978). Infestations by these beetles usually remain undetected for a long period. Untreated infestations result in severe losses manifested in lower yields, lower date quality, and death of trees, especially young transplants.

The Date Palm Fruit Stalk Borer, O. elegans is the most common Oryctes species in Saudi Arabia (Walker and Pittaway, 1987) and is widely distributed throughout all date palm growing areas in the Kingdom. Adults feed on tender leaves, inflorescences and the fruit stalk of the fruit bunches of date palms. Males and females probe and feed on bases of fronds and fruit stalks, thus sometimes causing wilting of these parts and/or production of lower quality dates due to the lower supply of nutrients and water reaching them (Kadous et al., 1983; Talhouk, 1984).

The larvae of $O$. elegans (locally known as "AlAngara") thrive on decomposing dung and decaying plant matter such as the stumps and trunks of dead or weak palms. Larvae are also known to feed on the roots of date palms.

Light traps have been introduced by many researchers as means of monitoring beetle populations, as well as a method of physical control (FAO, 2002; Dillon and MacKinnon, 2002). In this current study, light traps were used as a monitoring tool to detect the time of appearance of adult O. elegans in Al-Qassim date palm plantations and to provide data regarding associated adult activity (mating, egg laying), the size of the population, and the number of generations. In addition, the traps were expected to serve as a physical means of reducing densities of mating beetles (FAO, 2002; Dillon and MacKinnon, 2002).

It is anticipated that the results of this investigation will facilitate improved management of $O$. elegans, which will be reflected in increased yields and healthier stands of date palms.

\section{Materials and Methods}

Al-Rajhi Endowment, the largest date palm plantation in Al-Qassim Region, with an area of 200 ha and with more than 200,000 cultivated palm trees, was used as the site of this study. Three modified Robinson light traps (2 m high, supplied with mercury-vapor light, collecting funnel about $25 \mathrm{~cm}$ dia., and insect collection jar half filled with diesel) were installed at three different sites. Light trap \#1 was situated in the middle of an area in which Barhi, Sukari, Khlas and Nabtat Ali date palm lines were grown. Trees were 8-9 years old with an average height of $2.5 \mathrm{~m}$. Light trap \#2 was located in an empty central area (containing stores, refrigerated rooms and other buildings) between areas in which traps \# 1 and \#3 were situated. Light trap \#3 was situated in an area under trees of the Razizi, Maktumi, Shagra and Nabtat Ali lines, which were more than 18 years old, and with an average height of $7.5 \mathrm{~m}$.

The light traps were operated daily from sunset to sunrise, for a whole year, from June 2003 until June 2004. Collected insects were removed from traps on a daily basis. Catches were sorted out and positively identified $O$. elegans were separated out and counted. Catches of $O$. elegans per trap were pooled monthly.

\section{Results and Discussion}

Oryctes elegans was the dominant beetle, compromising more than $95 \%$ of all beetles captured in light traps during the study period. Table 1 outlines the monthly catches of $O$. elegans adults in the three light traps. The number captured each night varied in the three light traps throughout the study period. Windy and rainy conditions reduced beetle flight. However, no meteorological data were available to correlate with catches of $O$. elegans. The effective light range of light traps also varied substantially with the intensity of moonlight, such that on dark nights traps caught more beetles. The mean catching rate ranged from 11.8 to 85.5 beetles/trap/week, which can be considered to be indicative of a high infestation rate. The total number of Oryctes beetles captured in the three traps was 5559. Presuming a sex ratio of 1:1, this gives 2780 laying females.

While no beetle activity at all was observed during January and February 2004, no evidence exists that 
Table 1. Mean number of Oryctes elegans adults captured in 3 light traps during the period of June 2003 to June 2004 in a large date palm plantation in Al-Qassim, Saudi Arabia. See methods for description of sites.

\begin{tabular}{lrrr}
\hline \multirow{2}{*}{ Month } & \multicolumn{3}{c}{$\begin{array}{c}\text { Number of Oryctes adults } \\
\text { captured in }\end{array}$} \\
\cline { 2 - 4 } & Trap 1 & Trap 2 & Trap 3 \\
\hline June 2003 & 245 & 119 & 527 \\
July & 136 & 55 & 469 \\
August & 101 & 45 & 233 \\
September & 89 & 25 & 92 \\
October & 22 & 21 & 78 \\
November & 50 & 0 & 62 \\
December & 17 & 0 & 48 \\
January 2004 & 0 & 0 & 0 \\
February & 0 & 0 & 0 \\
March & 34 & 0 & 21 \\
April & 215 & 97 & 492 \\
May & 97 & 130 & 817 \\
June & 639 & 273 & 310 \\
\hline Total & 1645 & 765 & 3149 \\
Grand total = 5559 & & & \\
\hline Monthly average & 126.54 & 58.85 & 242.23 \\
Percent of all & 29.60 & 13.80 & 56.60 \\
captures & & & \\
\hline & & &
\end{tabular}

$O$. elegans goes into hibernation in the adult stages during the winter months (from mid-December to mid-March). Beetles showed up gradually in small numbers until April 2004 when a sudden outbreak was evident, the total number captured during this month in the three light traps was 804 beetles, comprising about $14.5 \%$ of the total catch of the year. April, May, June and July witnessed the highest activity of O. elegans, with $65 \%$ of the total yearly catch made during this period. Peak activity of $O$. elegans was observed during the month of June, when 16 and $22 \%$ of the population was collected during 2003 and 2004, respectively. Similar results were reported by Talhouk (1982) who stated that in Al-Kharj and Al-Houfouf in Saudi Arabia O. agamemnon becomes active in April and reaches its peak activity from June to August. This same species was active from the end of April to the end of September in Wadi Qurayat in northern Oman, with a peak in June (Mokhtar et al., 2000).

Among the three trap sites, the highest number of beetles was recovered in light trap \# 3, in the area under tall palms over 18 years old, where $56.6 \%$ of the total yearly catch was caught. Next in percentage of catches was light trap \#1 in the area of shorter and younger palms. This trap caught $29.6 \%$ of all beetles. Trap \#2 in the uncultivated area, caught the lowest percentage of $O$. elegans $(13.8 \%)$.

It is possible that $O$. elegans has a preference for older palms. In more mature plantations, decomposing organic matter and weak dying palms are expected to be more plentiful. These can be hypothesized to provide a good source of food for the beetle's progeny and to supply good oviposition sites for adult beetles. It is documented that the eggs of $O$. elegans are laid in decomposing matter, and weak palm trees with decaying moist parts provide beetle larvae (Martin, 1967; Hussein, 1974; FAO, 2002) with a good food source.

Another explanation for the differences in $O$. elegans catches among the three traps is variability in the degree of darkness among the three sites. The degree of darkness was highest in the area of light trap \# 3 (tall, old palms), followed by trap \# 1 (short, young palms), and then trap \#2 (uncultivated field). This perhaps explains why the trap catches were consistently biased in favor of light trap \# 3 .

\section{Acknowledgements}

We would like to thank the Deanship of Scientific Research at King Saud University for funding this project. Also many thanks to Al-Rajhi Endowment Management at Albatin, Buraydah, for allowing to use the date palm plantation for this project and their endless help in maintaining and sampling the traps.

\section{References}

Carpenter, J.B. and H.S. Elmer. 1978. Pests and Diseases of Date Palm. USDA Agricultural Handbook No. 527.

Dillon, M. and L. MacKinnon. 2002. Using light traps to suppress Helicoverpa. The Australian Cottongrower 23:32-36.

FAO, 2002. Date Palm Cultivation. A. Zaid (Editor). FAO Plant Production and Protection Paper No. 156, Rev. 1. 
Gharib, A. 1970. Oryctes elegans Prell. (Coleoptera, Dynastidae). Applied Entomology Phytopathlogy (Tehran) 29:10-12 (In French), 10-19 (In Iranian).

Hussein, A. 1974. Date palms and dates with their pests in Iraq, 166pp. University of Baghdad, Ministry of Higher Education Science Research.

Kadous, A.A., S.M. Hammad and M.M. Ramadan. 1983. Assessment of damage inflicted upon date palms by Pseudophilus testaceus Gahan and Oryctes elegans Prell in Al-Hassa Oasis. In: Proceeding of the 1st Symposium on Date Palm. King Faisal University, Hofuf, Saudi Arabia. pp 698-699.

Martin, H. 1967. Report to the Government of Iraq on Cereal and Tree Pests. FAO Report No. TA2330, Rome.

Mokhtar, A.M., S.S. Al-Nabhani and S.S. Al-Tamimi. 2000. Seasonal abundance of the fruit-stalk borer Oryctes agamemnon (Burn.) (Coleoptera: Scarabaeidae) in date palm plantations in Wadi Quriyat, AlDakhlyia region. Annual Report of
Entomology, Jimah Research Station, Ministry of Agriculture and Fisheries, Sultanate of Oman, pp. 44-46.

Talhouk, A.S. 1982. The present status of date palm pests in Saudi Arabia. Proceedings of the First Symposium on the Date Palm held at King Faisal University, Al-Hassa, Saudi Arabia, March 23-25, 1982.

Talhouk, A.S. 1984. Insect pests most spreading in the Kingdom of Saudi Arabia and ways to suppress them. Ministry of Agriculturre and Water, Riyadh, Saudi Arabia.

Talhouk, A.S. 1991. On the management of the date palm and its arthropod enemies in the Arabian Peninsula. Journal of Applied Entomology 111: 514-520.

Walker, D.H. and A.R. Pittaway. 1987. Insects of Eastern Arabia. Macmillan Publishers Ltd., London.

Received: June 2005

Accepted: November 2007 